Edu Sciences J. Vol. 1, No. 2. July 2020, 80-89

\title{
STUDY OF RESIDENTIAL SETTLEMENTS TOWARDS SPATIAL IN PASSO REGION, AMBON CITY
}

\author{
W. S. Pinoa \\ Geographic Study Program \\ Faculty of Education and Teacher Training - Pattimura University \\ email: pinoawc@gmail.com
}

\begin{abstract}
Passo region is in accordance with the results of observation, many residential buildings are located in protected areas, commensurate with the coast, commensurate with rivers and around the spring, as well as buildings that do not have a building permit. IMB seems easy to obtain without taking into account the City Planning and Spatial Planning. Hence why, the writer cunducting the research with the title "Study of Residential Settlements Towards Spatial in Passo Region, Ambon City".
\end{abstract}

Keywords : building permit (IMB)

\section{Introduction}

Passo region is one of the places of population concentration in Ambon city, with all the population activities taking place in this area. In addition, the Passo is a center for economic, social, cultural, political, economic and administrative activities. There are centers for the provision of facilities, industry, trade, capital and inter-city terminals. This means that Passo Region will have multiple functions, namely as a center for settlements, government, trade, transportation and cultural centers that have direct influence with the surrounding area. Therefore, it is necessary to regulate and control the physical development of human settlements so that order and peace can be achieved.

The concept of spatial planning in Passo region must be in accordance with the guidelines of the Directorate of Urban Development, namely the implementation of urban development in three main ways, namely: 1). Spatial planning process. 2). Space Utilization 3 ). Control of spatial use is carried out through supervision and control of spatial use. The purpose of carrying out the construction of settlements that are not based on spatial planning is to be subject to sanctions namely Civil and Criminal Sanctions (Anonimus, 2003).

\section{a. Spatial Planning in Passo}

The policy that determines the location of the area that must be protected and cultivated and includes plans for the use of regional space to maintain the harmony of development between sectors. This is in the context of preparing and controlling the development program in the long term with a period of 10 years, including: Protected forest areas, the criteria for setting are: slope factor, soil type, rainfall intensity, slope more than $40 \%$ and altitude above $200 \mathrm{~m}$. Peatland areas, the criteria for determination are: peat thickness of more than $3 \mathrm{~m}$ is located upstream or swamp. Water catchment areas, the criteria for determination are: high rainfall, easy soil to be infused with water, a form that makes it easy to absorb large amounts of water. River border, the criteria for setting are: $5 \mathrm{~m}$ outside the river pelvis, if there is no 
pelvis, an authorized official is determined. Beach border, the criteria for setting are: $100 \mathrm{~m}$ from the highest tide point along the coast. The area around the lake (reservoir), the determination criteria are: 50-100 $\mathrm{m}$ from the edge of the lake at high tide. The area around the spring, the criteria for setting are: $200 \mathrm{~m}$ around the spring.

\section{b. Formulation of RT/RW in Passo}

Seeing the condition, resource potential, accessibility and availability of facilities and infrastructure, development patterns, Passo is located in the Development Area Unit II (SWP), covering Passo sub-district and Hutumuri sub-region with a service center in Passo.

\section{a) The definition of Spatial Use Control}

The legal basis of Article 17 and 18 of Law Number. 24 of 1992, namely: (Article 17), Control of spatial use is carried out through supervision and control of spatial use as well as through licensing mechanisms for Regency / City areas. (Article 18) paragraph: (1) Supervision of the use of space is carried out in the form of reporting, monitoring and evaluation. (2) Control of spatial use that is not in accordance with the spatial plan is carried out in the form of the imposition of sanctions in accordance with applicable laws (Anonimous, 1992). Sulkaidi (1999: 112) equipment in controlling spatial use (land) consists of licensing, supervision and control. Jayadinata (1999: 59) argues that spatial / land control and supervision is an effort to continuously and consistently direct the use of spatial use and development, that have been determined so that every community activity can play a role in it through licensing.

Based from the opinions above, it is hoped that the spatial structure of the Passo Region will be controlled, the environment maintained and mutually beneficial to all residents who live. Referring to the development of the Ambon City spatial plan that was compiled, it was agreed to be guided (Ambon City Spatial Plan 2003 - 2013).

\section{b) Developement Direction for Developed Areas}

If Passo Region Spatial Plan is not implemented properly, will cause various social problems in the community. Therefore, the control tool in arranging residential buildings in Passo is the IMB (Building Permit) service. This is supported by the Governor's Instruction dated August 4, 1994 and Ambon Mayor Decree No. 614/2125 dated September 5, 1995, in which the provisions on criminal levies for building permits No. 8 of 2001, Chapter XXI Article 27 reads: 1) Mandatory levies that do not carry out their obligations so as to prejudice the area threatened with imprisonment no longer than 9 (nine) times the amount of retribution owed. 2). The criminal act referred to in paragraph 1 is a violation.

The fact that is happening right now in Passo, is related to the spatial layout of the Passo region that IMB services are still in a poor condition. It is proven that there are many residential buildings in the mountain slopes, (protected forest) commensurate with the river (DAS), commensurate with the beach, and a lot of illegal buildings (at will to choose building land). IMB looks easy to obtain without taking into account the City Planning and Spatial Planning. Hence why, the writer cunducting the research with the title "Study of Residential Settlements Towards Spatial in Passo Region, Ambon City".

The objectives of the study are knowing the level of understanding of the community about the residential building layout of the spatial (spatial function) in Passo that has been 
determined. And also to knowing the level of implementation of the control of residential settlement building arrangements for spatial planning in Passo region by the government. Next, to knowing the deviation in the implementation of residential settlement building system towards spatial planning in the Passo Region by residents.

\section{Research Methods}

a. Research Variable:

Understanding of residents of the Passo region regarding settlement and spatial planning, with its indicators: a). Space Utilization (TR); b). Building arrangements (IMB); c). What are the risks, and Implementation of the control of the spatial structure of the spatial by the government, the indicators are: a). Planning; b). Licensing; c). Supervision; d). Control

b. Population and Research Samples

The population of this study is also used as a sample in this paper, with the consideration that the problem under study is homogeneous / homogeneous, then the total population taken is 25 respondents.

c. Data Analysis

After the data is collected, the writer analyzes it by:

- For problem number 1, the writer uses descriptive statistics (Haryo Kungoro, Dr. 2008). Technically this analysis expresses data by means of cross tabulation. Tabulation results and presentation calculations are explained descriptively.

- For problem number 2, the author uses Descriptive Analysis of the process of building control, by owning or not having a building permit.

For problem number 3, from each indicator the author uses the formula:

Very good, with a score of 4 If You Have a Building Permit and In Accordance With Ambon City RTRW.

Good, with a score of 3 If You Don't Have a Building Permit But In Accordance With The Ambon City RTRW.

Less, with a score of 2 If You Have a Building Permit But It Is Not In Accordance With The Ambon City RTRW.

Not good, with a score of 1 If You Don't Have a Building Permit And Are Not In Accordance With The RTRW Of Ambon City.

\section{Result and Discussion}

a. Overview of Research Location

Topography: $73 \%$ of the total area can be categorized as sloped, with a slope above $20 \%$. Only $17 \%$ of the land area can be classified as flat or sloping with a slope of less than $20 \%$. The general topography of the Passo Region can be grouped as follows:

Received April $18^{\text {th }} 2020$, Revision May $18^{\text {th }} 2020$, Accepted for publication June $18^{\text {th }} 2020$.

Copyright (C) 2020 Published by FKIP - Unpatti, ISSN 2721-3110 
1) The topography is relatively flat with a height of $0-20$ meters and a slope of $0-10 \%$ is found in the area along the coast with a radius between 0 - 300 meters from the coastline.

2) Sloping topography to be tilted with a height of 20 - 30 meters and a slope of $10-20 \%$ is found in areas farther from the coastline (100 meters and above).

3) Corrugated and steep hilly topography with a height of 20-50 meters and a slope of 20$30 \%$ found in the hilly area.

4) Steep topography with a height of $>50$ meters and a slope of $>30 \%$ is found in mountainous regions.

The development of land use in the Passo Region has experienced changes or shifts in land use over the last 5 years, in which many are caused by the existence of newly built houses. This development trend needs special attention, especially in the development of settlements with slopes> $30 \%$ and in the downtown area.

b. Type of Building Built

There are several ways of building settlements that are found at three points in the Passo, namely:

1). Individual development

2). Development by development bearers

3). Improvement of the village

4). Urban land consolidation.

The four methods, generally methods 2,3 and 4 have no problem regarding the IMB. But the first method found problematic about IMB. This means that individual development often does not touch the management of IMB. The status of respondents' land ownership at the service center is shown in Table 1.

Table 1. Respondent Land Ownership Status

\begin{tabular}{|c|c|c|c|c|c|c|c|c|c|}
\hline \multirow{2}{*}{ No. } & \multirow{2}{*}{$\begin{array}{c}\text { Service } \\
\text { center }\end{array}$} & \multicolumn{4}{|c|}{ Land Ownership Status } & \multicolumn{3}{|c|}{ Total } \\
\cline { 3 - 9 } & Gifted & Custom & Buy & & F & \\
\hline 1 & Passo & 5 & 5 & & 15 & & 25 & \\
\hline & Total & 5 & 5 & & 15 & 25 & \\
\hline
\end{tabular}

Source : Processed products

Table 1 illustrates that the dominant status of land ownership is the status of land acquired from the purchase of 15 respondents, the status of customary land 5 respondents and 5 more respondents is the status of land given by parents / family. And the forms of buildings in Passo are shown in Table 2, while Table 3 shows the number of buildings that have a building permit and those that do not have a building permit. 
Table 2. Number of Buildings Per Service Center Owned by Respondents

\begin{tabular}{|c|c|c|c|c|c|}
\hline \multirow{3}{*}{ No. } & \multirow{3}{*}{$\begin{array}{l}\text { Service } \\
\text { Center }\end{array}$} & \multicolumn{3}{|c|}{ Number of Houses } & \multirow{3}{*}{$\begin{array}{l}\text { Number of } \\
\text { Respondents }\end{array}$} \\
\hline & & Permanent & $\begin{array}{c}\text { Semi- } \\
\text { Permanent }\end{array}$ & $\begin{array}{c}\text { Temporar } \\
\mathbf{v}\end{array}$ & \\
\hline & & $\mathbf{F}$ & $\mathbf{F}$ & $\mathbf{F}$ & \\
\hline 1 & Passo & 15 & 5 & 5 & 25 \\
\hline \multicolumn{2}{|r|}{ Total } & 15 & 5 & 5 & 25 \\
\hline
\end{tabular}

Source : Processed Products

Table 3. Types of Respondent Buildings that Have a Building Permit

\begin{tabular}{|c|l|c|c|c|c|}
\hline \multirow{2}{*}{ No } & \multirow{2}{*}{ Passo Region } & \multicolumn{3}{|c|}{ Jumlah Rumah } & \multirow{2}{*}{ Total } \\
\cline { 3 - 6 } & & \multirow{2}{*}{ Permanent } & Semi-Permanent & \multirow{2}{*}{ Temporary } & F \\
\hline 1 & - Have IMB & 2 & 3 & - & 5 \\
\hline 2 & $\begin{array}{l}\text { - Dont not have } \\
\text { IMB }\end{array}$ & 10 & 6 & 4 & 20 \\
\hline & Total & 12 & 9 & 4 & 25 \\
\hline
\end{tabular}

Source : Processed Products

Table 3 illustrates that, the number of respondent houses that do not have a building permit is 20 respondents, consisting of 10 respondents 'permanent homes, 6 respondents' semi-permanent houses, and 4 temporary houses. While those who have a building permit are only 5 respondents, consisting of 2 respondents' permanent homes and 3 semi-permanent homes. If seen from the side of the service center area, it is illustrated in Table 4.

Table 4. Number of Respondent Buildings Per Service Center Area that Has a Building Permit (IMB)

\begin{tabular}{|c|c|c|c|c|}
\hline No & Service Center & Have IMB & $\begin{array}{c}\text { Don't } \\
\text { Have }\end{array}$ & F \\
\hline 1 & Passo & 5 & 20 & 25 \\
\hline \multicolumn{2}{|c|}{ Total } & 5 & 20 & 25 \\
\hline
\end{tabular}

Source : Processed Products

Table 4 illustrates that respondents who did not have a building permit when building a house (a place to live) numbered 20 respondents. Their reason is seen in table 5.

Table 5. Reasons - Respondents Did Not Have a Building Permit (IMB)

\begin{tabular}{|c|c|c|c|c|c|c|}
\hline \multirow{2}{*}{ No } & \multirow{2}{*}{ Service Center } & \multicolumn{4}{|c|}{ Reason for Respondents } & Total \\
\cline { 3 - 7 } & & $\begin{array}{c}\text { Personal } \\
\text { Rights }\end{array}$ & $\begin{array}{c}\text { Convoluted } \\
\text { business }\end{array}$ & $\begin{array}{c}\text { Customary } \\
\text { Land }\end{array}$ & Other & F \\
\hline 1 & Passo Region & 17 & 3 & 5 & - & 25 \\
\hline & Total & 17 & 3 & 5 & - & 25 \\
\hline
\end{tabular}

Source : Processed Products

Received April $18^{\text {th }} 2020$, Revision May $18^{\text {th }} 2020$, Accepted for publication June $18^{\text {th }} 2020$.

Copyright @ 2020 Published by FKIP - Unpatti, ISSN 2721-3110 
Table 5 illustrates that the reason respondents do not have a building permit is because the house is a private right.

The lack of Government socialization about IMB to the public can be seen in Table 6 .

Table 6. Number of Respondents Participating in IMB Socialization Activities

\begin{tabular}{|c|c|c|c|c|}
\hline \multirow{2}{*}{ No } & \multirow{2}{*}{ Service Center } & \multicolumn{2}{|c|}{ Following the IMB Socialization } & Total \\
\cline { 3 - 5 } & & Ever & Never & F \\
\hline 1 & Passo Region & - & 25 & 25 \\
\hline & Total & - & 25 & 25 \\
\hline
\end{tabular}

Source : Processed Products

Table 6 shows that the people of Passo Region did not understand the concept of building and spatial planning.

Table 7. Location of Area as Sample Area

\begin{tabular}{|c|l|c|}
\hline \multirow{2}{*}{ Service Center } & Regional Location & Total \\
\cline { 2 - 3 } & & F \\
\hline \multirow{3}{*}{ Passo Region } & Protected area & 6 \\
\cline { 2 - 3 } & Beach border & 6 \\
\cline { 2 - 3 } & Worth the beach & 6 \\
\cline { 2 - 3 } & Area Around Springs & 7 \\
\hline Total & & 25 \\
\hline
\end{tabular}

Source : Processed Products

c. Control Implementation of Population Building Settlements Against Spatial Planning in Passo Region

Identification and analysis of the variables of the control implementation of residential settlement building procedures to the spatial structure, referring to the reality so far by the Ambon City Government (City Planning Office). Ambon Mayor Decree Number 614/2125 dated September 5, 1995 Concerning General Arrangements for Building Permits, namely: 1). Prohibit and prevent any business development activities of housing or the like by utilizing the area around the river flow, steep slopes and the coast. 2). Conduct enforcement of any planned activities from the community to construct buildings with a radius of $10 \mathrm{M}$ to $15 \mathrm{M}$ from the river body (DAS), 100-200 M from the water source (seepage / catchment area) and a minimum of $25 \mathrm{M}$ from the tide boundary

d. Irregularities in the Implementation of Building Arrangements in Spatial Planning in the Passo Region

Deviations in the implementation of the system of building residential settlements to the spatial layout in the Passo region, a conformity matrix is made, where the evaluation criteria are: Spatial 
Edu Sciences J. Vol. 1, No. 2. July 2020, 80-89

Table 7. Spatial

\begin{tabular}{|c|c|l|}
\hline \multicolumn{2}{|c|}{ Score } & \multicolumn{2}{|}{ Criteria } \\
\hline Number & Word & \multicolumn{1}{|c}{} \\
\hline 1 & Very bad & Spatial Planning Does Not Fit, There Is No IMB \\
\hline 2 & Bad & $\begin{array}{l}\text { Spatial Planning Is Not Suitable, But There Is A Building } \\
\text { Permit }\end{array}$ \\
\hline 3 & Good & Spatial Planning Appropriate, But There Is No IMB \\
\hline 4 & Very good & Spatial Planning Appropriate, There is an IMB \\
\hline
\end{tabular}

Table 8. Protected area

\begin{tabular}{|c|c|c|}
\hline \multicolumn{2}{|c|}{ Score } & Criteria \\
\hline Number & Word & $>60 \%$ Slope \\
\hline 1 & Very bad & $41-60 \%$ Slope \\
\hline 2 & Bad & $21-40 \%$ Slope \\
\hline 3 & Good & $0-20 \%$ Slope \\
\hline 4 & Very good & \\
\hline
\end{tabular}

Table 9. Beach Borders

\begin{tabular}{|c|c|c|}
\hline \multicolumn{2}{|c|}{ Score } & \multicolumn{2}{c}{ Criteria } \\
\cline { 1 - 2 } Number & Word & \\
\hline 1 & Very bad & $0-12 \mathrm{~m}$ from the highest tide towards the land \\
\hline 2 & Bad & $13-25 \mathrm{~m}$ from the highest tide towards the land \\
\hline 3 & Good & $26-38 \mathrm{~m}$ from the highest tide towards the land \\
\hline 4 & Very good & $>38 \mathrm{~m}$ from the highest tide towards the land \\
\hline
\end{tabular}

Table 10. River Borders

\begin{tabular}{|c|c|c|}
\hline \multicolumn{2}{|c|}{ Nilai } & Criteria \\
\hline Number & Word & $0-7 \mathrm{~m}$ from Das \\
\hline 1 & Very bad & $8-15 \mathrm{~m}$ from Das \\
\hline 2 & Bad & $16-24 \mathrm{~m}$ from Das \\
\hline 3 & Good & $>24 \mathrm{~m}$ from Das \\
\hline 4 & Very good & \\
\hline
\end{tabular}

Table 11. Regions Around the Springs

\begin{tabular}{|c|c|c|}
\hline \multicolumn{2}{|c|}{ Nilai } & Criteria \\
\hline Number & Word & $0-100 \mathrm{~m}$ from the spring \\
\hline 1 & Very bad & $101-200 \mathrm{~m}$ from the spring \\
\hline 2 & Bad & $201-300 \mathrm{~m}$ from the spring \\
\hline 3 & Good & $>300 \mathrm{~m}$ from the spring \\
\hline 4 & Very good & \\
\hline
\end{tabular}


Based on the assessment results show the criteria in the tables above (tables 7-11), will be seen in Table 12 .

Table 12. Conformity Analysis of Building Arrangement with Respondents' Spatial Planning

\begin{tabular}{|c|c|c|c|c|c|c|c|c|c|c|c|c|c|c|c|c|c|}
\hline \multirow{3}{*}{$\begin{array}{l}\text { Service } \\
\text { Center }\end{array}$} & \multirow{3}{*}{$\begin{array}{c}\text { Serial No } \\
\text { Respond } \\
\text { ents }\end{array}$} & \multicolumn{4}{|c|}{ Protected area } & \multicolumn{4}{|c|}{$\begin{array}{c}\text { Beach } \\
\text { border }\end{array}$} & \multicolumn{4}{|c|}{$\begin{array}{l}\text { River } \\
\text { border }\end{array}$} & \multicolumn{4}{|c|}{$\begin{array}{c}\text { Water } \\
\text { springs }\end{array}$} \\
\hline & & \multicolumn{16}{|c|}{ Tata Ruang } \\
\hline & & 1 & 2 & 3 & 4 & 1 & 2 & 3 & 4 & 1 & 2 & 3 & 4 & 1 & 2 & 3 & 4 \\
\hline \multirow{25}{*}{$\begin{array}{l}\text { Passo } \\
\text { Region }\end{array}$} & 1 & & 1 & & & & & & & & & & & & & & \\
\hline & 2 & 1 & & & & & & & & & & & & & & & \\
\hline & 3 & & 1 & & & & & & & & & & & & & & \\
\hline & 4 & & 1 & & & & & & & & & & & & & & \\
\hline & 5 & & 1 & & & & & & & & & & & & & & \\
\hline & 6 & & 1 & & & & & & & & & & & & & & \\
\hline & 7 & & & & & & 1 & & & & & & & & & & \\
\hline & 8 & & & & & 1 & & & & & & & & & & & \\
\hline & 9 & & & & & & 1 & & & & & & & & & & \\
\hline & 10 & & & & & 1 & & & & & & & & & & & \\
\hline & 11 & & & & & 1 & & & & & & & & & & & \\
\hline & 12 & & & & & & & & 1 & & & & & & & & \\
\hline & 13 & & & & & & & & & & & & 1 & & & & \\
\hline & 14 & & & & & & & & & 1 & & & & & & & \\
\hline & 15 & & & & & & & & & & 1 & & & & & & \\
\hline & 16 & & & & & & & & & & & 1 & & & & & \\
\hline & 17 & & & & & & & & & & & 1 & & & & & \\
\hline & 18 & & & & & & & & & 1 & & & & & & & \\
\hline & 19 & & & & & & & & & & & & & & & 1 & \\
\hline & 20 & & & & & & & & & & & & & & 1 & & \\
\hline & 21 & & & & & & & & & & & & & & 1 & & \\
\hline & 22 & & & & & & & & & & & & & & & 1 & \\
\hline & 23 & & & & & & & & & & & & & & 1 & & \\
\hline & 24 & & & & & & & & & & & & & & & 1 & \\
\hline & 25 & & & & & & & & & & & & & & 1 & & \\
\hline
\end{tabular}

Source: Processed Products

To calculate the degree of deviation in the settlement structure of the population to the spatial structure, the value of the spatial structure is multiplied by the spatial structure value, the results are shown in Table 13 below: 
Edu Sciences J. Vol. 1, No. 2. July 2020, 80-89

Tabel 13. Kategori Penyimpangan Tata Bangun Terhadap Tata Ruang Di Kawasan Passo

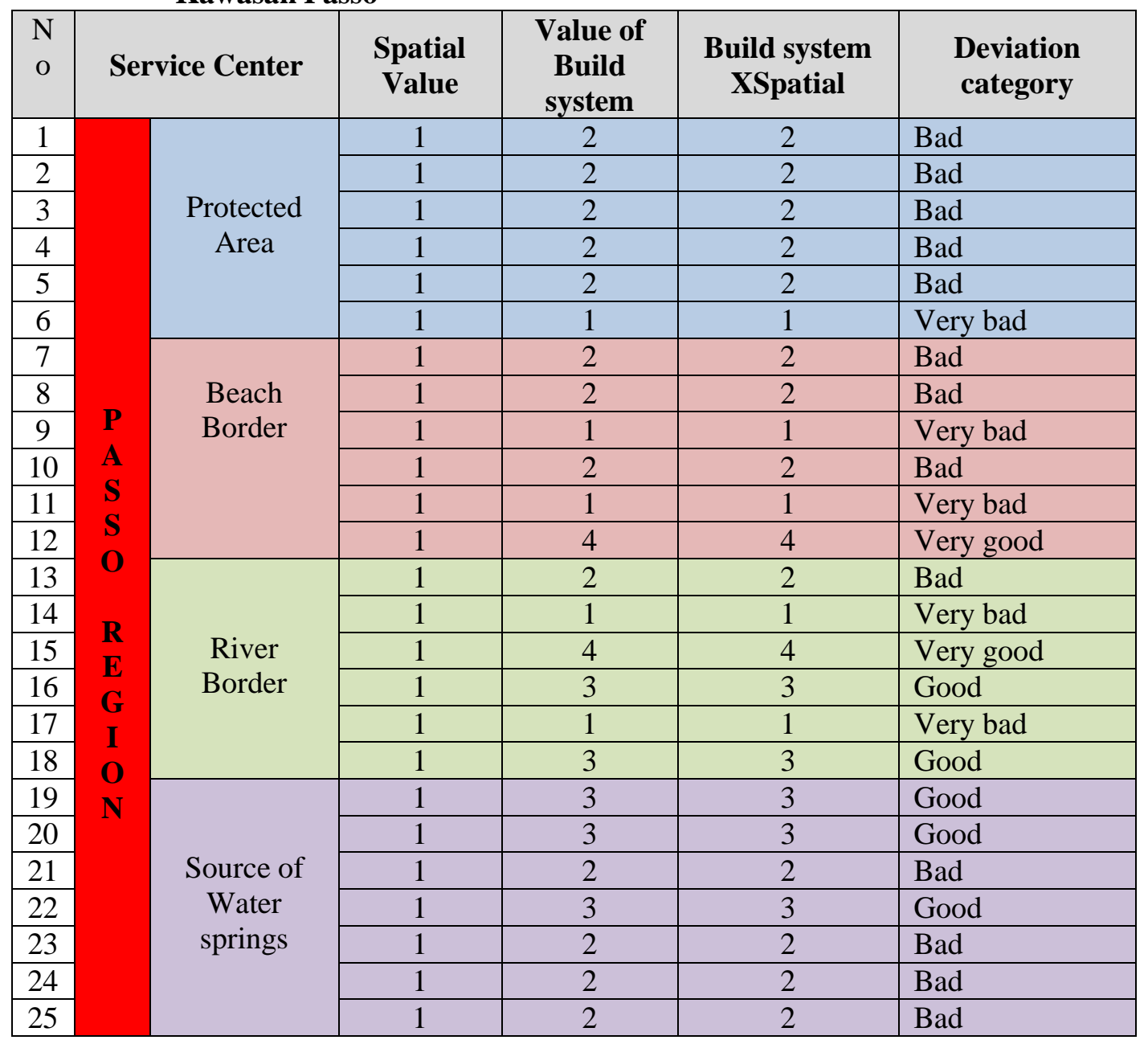

Source : Processes Products

*) Note: $1=$ There are no deviations

$2=$ There is a deviation

Table 13 shows that out of 25 respondents, only 5 respondents did not experience deviations when they built houses. And most or 20 respondents have deviations.

Table 14. Degree of Build Deviations against Spatial Planning in the Passo Region

\begin{tabular}{|c|c|c|c|c|c|}
\hline \multirow{2}{*}{ Degree of Deviation } & \multicolumn{4}{|c|}{ Passo Region } & \multirow{2}{*}{ Total } \\
\cline { 2 - 6 } & $\begin{array}{c}\text { Protected } \\
\text { area }\end{array}$ & $\begin{array}{c}\text { Beach } \\
\text { Border }\end{array}$ & $\begin{array}{c}\text { River } \\
\text { Border }\end{array}$ & $\begin{array}{c}\text { Source } \\
\text { of water } \\
\text { springs }\end{array}$ & \\
\hline There are no deviations & - & 1 & 3 & 3 & 7 \\
\hline Deviations & 6 & 5 & 3 & 4 & 18 \\
\hline Total & 6 & 6 & 6 & 7 & 25 \\
\hline
\end{tabular}

Received April $18^{\text {th }} 2020$, Revision May $18^{\text {th }} 2020$, Accepted for publication June $18^{\text {th }} 2020$.

Copyright @ 2020 Published by FKIP - Unpatti, ISSN 2721-3110 
Table 14 illustrates the level of deviation in the construction of residential settlements to the layout in the Passo Region is quite large / many. I.e. 18 respondents and only 7 respondents did not experience deviations.

e. What Factors Are Very Influential About Deviations in Residential Building Construction on Spatial Planning in Passo

Based on the results of the analysis, it can be formulated several factors that influence the deviation of the residential settlement building system to the spatial layout in the Passo Region, namely. Low understanding of the community about the importance of IMB, Ineffective model of socialization by the Government, The oversight function by the Government is still not optimal, Lack of supporting facilities (facilities and infrastructure) in supporting the implementation of supervision, Limited supervisors in terms of quality and quantity, Origins of land ownership, Post-conflict conditions, Lack of coordination with related agencies, The government's lack of firmness in cracking down on any violations that occur.

\section{Conclusion}

The level of Build Deviations Against Spatial Planning in the Passo Region is quite large/Many. Namely 18 respondents. And only 7 respondents did not experience deviations. The lack of public understanding of the importance of Building Permit (IMB), due to the lack of effective socialization by the Government. Therefore, it is expected that the government will be more assertive in socializing the importance of the IMB, as well as taking action against any violations that occur both in the property of individuals or joint ventures, in terms of Building Permit in Ambon City in general and Passo in particular.

\section{REFERENCES}

Anonymous, 1992. Undang-Undang Nomor 4 Tahun 1992, Tentang Perumahan dan pemukiman.

, 2003-2013. Rencana Tata Ruang Wilayah Kota Ambon. Pemerintah Daerah Kota Ambon, Badan Perencanaan Pembangunan Daerah.

Bintarto, R. 1979. Metode Analisa Geografi. LP3ES.

Eko Budihardjo, 1992. Sejumlah Masalah Pemukiman Kota, Penerbit Alumni, Bandung.

Haryo Kungoro, Dr. 2008. Statestik Deskriptif. Lembaga Penerbit Fakultas Ekonomi Universitas Indonesia.

H. Moh. Pabundu Tika, 2005. Metode Penelitian Geografi. Penerbit Bumi Aksara.

Sailadien, Drs. Konsep Dasar Demografi. Penerbit PT. Bina Ilmu Surabaya.

Sinulingga, B.D, 2005. Pembangunan Kota, Tinjauan Regional dan Lokal. Pustaka Sinar Harapan.

Widoyo Alfandi, 2001. Epistemologi Geografi. Gadjah Mada Universitas Pres

Received April $18^{\text {th }} 2020$, Revision May $18^{\text {th }} 2020$, Accepted for publication June $18^{\text {th }} 2020$.

Copyright @ 2020 Published by FKIP - Unpatti, ISSN 2721-3110 